\title{
DEFECTIVE CD2 PATHWAY T CELL ACTIVATION IN SYSTEMIC LUPUS ERYTHEMATOSUS
}

\author{
DAVID A. FOX, JO ANN MILLARD, JONATHAN TREISMAN, WENDY ZELDES, ALICE BERGMAN, \\ JOEL DEPPER, ROBERT DUNNE, and W. JOSEPH MCCUNE
}

CD2 (T11; sheep erythrocyte receptor) is the surface component of an alternative, antigen-independent pathway of human $T$ cell activation. The response to certain anti-CD2 antibodies is relatively independent of accessory cell signals and therefore provides a direct measurement of $\mathrm{T}$ cell function. The $\mathrm{CD} 2$ pathway may be important in the differentiation of thymocytes, on which the expression of $\mathrm{CD} 2$ precedes the appearance of the CD3-T cell receptor complex. In view of the impaired $T$ cell regulation of immune responses in patients with systemic lupus erythematosus (SLE), we examined the activation of peripheral blood lymphocytes by antiCD2 antibodies in 57 SLE patients and 32 normal control subjects. The $\mathrm{CD} 2$ pathway response was lower in the SLE patients $(P<0.0001) ; 18$ of the 57 SLE patients had a lower response than any of the control subjects. The SIE low-responder patients did not differ from the normal-responder patients in terms of disease activity or use of antiinflammatory and immunosuppressive medications. Low responses to anti-CD2 were corrected to normal by the coaddition of a submitogenic amount of phorbol myristate acetate $(1 \mathrm{ng} / \mathrm{ml})$. In some

From the Division of Rheumatology, Rackham Arthritis Research Unit, Department of Internal Medicine, and the Multipurpose Arthritis Center, University of Michigan Medical Center, Ann Arbor.

Supported by the L upus Foundation of America. Dr. Fox's work is supported by an Arthritis Foundation Investigator Award (Michigan chapter), by NIH grant AR-38477, and by the Leyota M. Wilson fund of the University of Michigan Mcdical School.

David A. Fox, MD; Jo Ann Millard, MSc; Jonathan Treisman, MD; Wendy Zeldes, BSc; Alice Bergman, BSc; Joel Depper, MD; Robert Dunne, BSc; W. Joseph McCune, MD.

Address reprint requests to David A. Fox, MD, Division of Rheumatology, R4570 Kresge Eye Institute, University of Michigan, Ann Arbor, MI 48109-0531.

Submitted for publication April 24, 1990; accepted in revised form November 14, 1990. low-responder patients, the responses were normalized by the removal of non- $T$ cells. The data indicate that some SLE patients have impaired responses to $\mathrm{CD2}$ pathway activation and that this may reflect intrinsic $\mathrm{T}$ cell defects and/or regulatory influences of non-T cells.

The clinical manifestations of systemic lupus erythematosus (SLE) are produced, in large part, by the effects of pathogenic autoantibodies. Underlying the B lymphocyte abnormalities in SLE, however, are disturbances in regulatory $\mathrm{T}$ cell function. $\mathrm{T}$ lymphopenia is common (1-3), and the proportions of $T$ cells in defined phenotypic/functional subsets are frequently deranged (2-6). T cell function in SLE patients is deficient in several ways, including proliferative responses (7-10), production of and response to interleukin-2 (IL-2) (11-17), generation of suppressor ccll function (18-22), and responses in the autologous mixed lymphocyte reaction $(21,23)$.

Anti-T cell autoantibodies probably play a major role in producing these abnormalities. Such antibodies are heterogeneous, and may be directed at structures on activated $T$ cells or on subsets required for the generation of suppressor function (24-31). A correlation has been found between the major antilymphocyte antibody specificity in the sera of individual patients and the concurrent abnormalities in the $T$ cell subsets and functions $(20,27,29,31)$.

It is now realized that multiple $\mathrm{T}$ lymphocyte surface structures are involved in the activation of resting $T$ cells. Prominent among these is the $T$ cell antigen receptor complex (CD3-TCR). A distinct structure, which has been termed CD2 (previously known as T11, and first identified as the $\mathrm{T}$ cell receptor for sheep erythrocytes [32]), can also convey activa- 
tion signals both to mature $\mathrm{T}$ cells and to thymocytes $(33,34)$. Although activation through CD2 was first demonstrated using combinations of anti-CD2 antibodies, similar effects have been found using a natural ligand of $\mathrm{CD} 2$, termed lymphocyte functionassociated antigen 3 (LFA-3; recently designated CD58) $(35,36)$. LFA-3 is an integral membrane component of cells with which $\mathrm{T}$ lymphocytes interact, such as thymic epithelial cells and monocytes (37).

In the course of recent studies of intravenous pulse cyclophosphamide treatment of severe SLE, it was observed that the in vitro proliferative response to anti-CD2 antibodies diminished during treatment and at followup, without a concurrent reduction in other $T$ cell responses (38). It was also apparent that the pretreatment response of the patients' $T$ cells to anti$\mathrm{CD} 2$ antibodies was frequently very low. Since abnormalities of CD2-mediated $T$ cell activation have not previously been documented in SLE, the present study was undertaken to investigate the integrity of this activation pathway in a large group of SLE patients with various levels of disease activity and severity. The results, when compared with those from the healthy control subjects, indicate that approximately $30 \%$ of SLE patients have very low proliferative responses to anti-CD2 antibodies. This low response cannot be explained by the level of disease activity or by the effects of medications.

\section{PATIENTS AND METHODS}

Patients and controls. Peripheral blood mononuclear cells were obtained from 57 patients with SLE ( 8 men and 49 women) who were receiving followup care at the University of Michigan Medical Center. These patients met the American Rheumatism Association 1982 revised criteria for the classification of SLE (39), and they had not been treated with cyclophosphamide. The mean \pm SD age of the patients was $34 \pm 11$ (range 19-62). Characteristics of these patients, who represented a wide range of disease manifestations and levels of activity, are described below (see Results).

The control group consisted of 32 healthy volunteers (14 men and 18 women), with a mean \pm SD age of $30 \pm 7$ (range 19-55). In certain experiments, additional mononuclear cell samples were obtained from SLE patients who had been treated with intravenous cyclophosphamide within the previous 3 months.

Activation of $\mathbf{T}$ cells. Mononuclear cells were isolated from heparinized peripheral blood by centrifugation over Ficoll-Hypaque (Pharmacia, Piscataway, NJ), followed by 3 washes in minimum essential medium containing $2 \%$ calf serum. For some experiments, $T$ cells $(E+)$ and non-T cells $(\mathrm{E}-)$ were separated by rosetting with sheep erythrocytes. Aliquots of 100,000 cells were cultured in RPMI 1640 me- dium with $10 \%$ fetal calf serum in 96-well round-bottom plates in a volume of $0.2 \mathrm{ml} /$ well. Triplicate wells contained either no stimulus or phytohemagglutinin (PHA) $(0.5 \mu \mathrm{g} / \mathrm{ml}$; Burroughs Wellcome, Research Triangle Park, NC), phorbol myristate acetate (PMA) (1 ng/ml; Sigma, St. Louis, MO), a mitogenic combination of 2 anti-CD2 monoclonal antibodies (anti-T1 $1_{2}$ and anti- $1_{1} 1_{3}$ [see ref. 33]), a mitogenic anti-CD3 antibody (anti-T3B [see ref. 40]), or tetanus toxoid (final concentrations 1:200 and 1:400; Massachusetts Department of Public Health, Boston, MA), or combinations of some of these stimuli. The monoclonal antibodies were generously provided by Drs. Stuart Schlossman and Ellis Reinherz (Dana-Farber Cancer Institute, Boston, MA), and were used at final concentrations of 1:500.

Cultures were maintained at $37^{\circ} \mathrm{C}$ in a humidified incubator with $5 \% \mathrm{CO}_{2}$. To detect cell proliferation, $0.8 \mu \mathrm{Ci}$ of tritiated thymidine was added on day 4 (day 6 for tetanus toxoid) and cultured for 18 hours. Cultures were then harvested using a multichannel instrument and counted in a liquid scintillation counter. Background counts per minute from unstimulated cultures were subtracted from the raw counts. For tetanus toxoid, the cpm from the dilution that yielded the higher proliferative response for an individual subject was selected.

Surface marker analysis. A panel of monoclonal antibodies was used to quantitate surface marker expression on mononuclear cells from patients with SLE and from control subjects. Markers assessed included pan-T cell antigens (CD2 and CD3), T cell subset markers (CD4, CD8, and CDw60), $T$ cell activation antigens (CD25 and CD26), HLA-DR, CD20 (a mature B cell antigen), CD56 (a natural killer cell antigen), and CD1 $1 \mathrm{~b}$ (expressed on monocytes and a small $T$ cell subset). Antibodies identifying $T$ cell antigens $(33,34,41-43)$, except for anti-CDw60 (44), were the generous gift of Drs. Stuart Schlossman and Ellis Reinherz. Other antibodies were generously provided by Drs. Lee Nadler (Dana-Farber Cancer Institute) $(45,46)$, Jerome Ritz (DanaFarber Cancer Institute) (47), and Robert F. Todd (University of Michigan) (48).

For surface marker analysis, aliquots of one million cells were incubated with optimal concentrations of monoclonal antibodies in a total volume of $0.2 \mathrm{ml}$ for 30 minutes at $4^{\circ} \mathrm{C}$. Following 2 washes, a saturating amount of fluoresceinconjugated goat anti-mouse immunoglobulin (Tago, Burlingame, CA) was added. After 30 minutes at $4^{\circ} \mathrm{C}$, the samples were again washed twice, fixed with $1 \mathrm{ml}$ of $1 \%$ formalin, and analyzed with an Epics $\mathrm{C}$ flow cytometer (Coulter, Hialeah, FL).

Measurement of interleukin-2 receptors (IL-2R). Mononuclear cells from patients with either high or low proliferative responses to anti-CD2 monoclonal antibodies (anti-T11 + anti-T $11_{3}$ ) were cultured with these antibodies (1:500) for 72-96 hours in RPMI 1640 medium with $10 \%$ fetal calf serum at two million cells per ml. Cultured cells were washed 5 times, and resuspended at a concentration of ten million viable cells per $\mathrm{ml}$ in binding medium containing RPMI 1640 with $1 \%$ bovine serum albumin, $1 \mathrm{mg} / \mathrm{ml}$ of human IgG, $25 \mathrm{~m} M$ HEPES, and $0.1 \%$ sodium azide. For measurement of total IL-2R, triplicate aliquots of one million cells were incubated with $19 \mathrm{ng}$ of tritiated anti-IL-2R (anti-Tac) monoclonal antibody for 60 minutes at room 
temperature in a total volume of $0.2 \mathrm{ml}$. The mixture was then layered over a $0.75 \mathrm{ml}$ sucrose cushion, centrifuged, and the cell pellet was recovered for liquid scintillation counting. Measurement of high-affinity receptors was done using similar procedures, but in the presence of $10-20 \mathrm{fM}$ IL-2 labeled with ${ }^{125} \mathrm{I}$ (Amersham, Arlington Heights, IL) and $20 \mathrm{p} M$ unlabeled IL-2 (Cetus, Emeryville, CA).

Measurement of IL-2 production. Supernatants of cells cultured for 48 hours with various activation stimuli were stored at $-80^{\circ} \mathrm{C}$, then added at dilutions of $1: 2$ to $1: 16$ to triplicate wells containing 5,000 CTLL-2 cells. Proliferation of the CTLL-2 indicator cells was quantitated by measuring thymidine incorporation following addition of 0.8 $\mu \mathrm{Ci}$ of tritiated thymidine per well for the final 6 hours of a 24-hour culture.

Induction of the $\mathrm{T}_{1} 1_{3}$ epitope. Incubation of $\mathrm{T}$ cells with anti- $\mathrm{T}_{1} 1_{2}$ for 30 minutes at $4^{\circ} \mathrm{C}$ induces expression of the $\mathrm{T} 11_{3}$ epitope (33). To determine if this occurred in $\mathrm{T}$ cells from SLE patients, $\mathrm{E}+$ cells were incubated with anti-T11 (IgG2) as described (33), then stained with anti-T11 (IgG3) $_{3}$ and fluoresceinated $\gamma 3$-specific anti-mouse IgG (The Binding Site, Birmingham, UK) or with control antibodies. Samples were then analyzed by flow cytometry.

Calcium fluxes. $T$ cells from SLE patients were suspended at a concentration of $20 \times 10^{6} \mathrm{cells} / \mathrm{ml}$ in culture medium (RPMI 1640 supplemented with $10 \%$ fetal calf serum, $1 \%$ glutamine, and $1 \%$ penicillin/streptomycin). Cells were loaded with the dye indo-1 (Molecular Probes, Eugene, $\mathrm{OR}$ ), at a concentration of $1.5 \mu M$, and maintained at $37^{\circ} \mathrm{C}$ for 25 minutes in the dark (49). Cells were washed 3 times and resuspended in culture medium. Aliquots of $10^{6}$ cells were kept on ice until they were placed in the flow cytometer. The ratio of violet:blue fluorescence was determined as a function of cell number; the change in the mean ratio was used as a measure of the extent of flux. Readings were taken at multiple time points after the addition of anti-CD2 antibodies (1:500) or ionomycin $(5 \mu \mathrm{g} / \mathrm{ml})$.

Statistical analysis. Responses of SLE and control T cells were compared using Student's $t$-test. Correlations within groups of SLE patients were determined by linear regression. Differences in $\mathrm{CD} 2$ responses between subsets of SLE patients were analyzed using the Wilcoxon rank sum test.

\section{RESULTS}

T cell proliferative responses to a panel of mitogenic stimuli were measured using mononuclear cells from 57 patients with SLE and 32 control subjects (Figure 1). The mean response to anti-CD2 antibodies in the SLE group was less than $60 \%$ of that in the control group, and this difference was highly significant $(P<0.0001)$. This result could not be explained by the higher proportion of males in the control group: The response of the male controls to CD2 activation was $63,128 \pm 9,931 \mathrm{cpm}$ (mean \pm SEM), which is not significantly different from that of the female controls $(69,283 \pm 7,573 \mathrm{cpm})$. Differences in proliferative responses between the SLE and control groups were

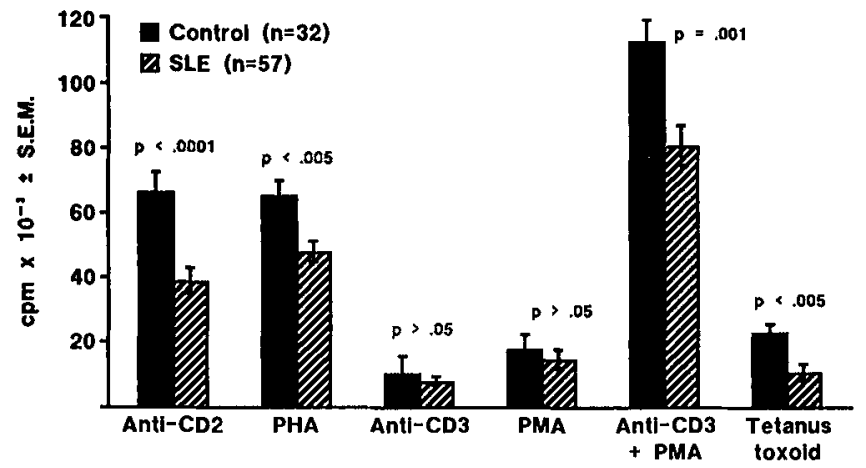

Figure 1. Proliferative responses of mononuclear cells from patients with systemic lupus erythematosus (SLE) and from healthy controls to various $\mathrm{T}$ cell stimuli. Proliferation was measured on day 4 of culture, except for tetanus toxoid, which was measured on day 6. $\mathrm{PHA}=$ phytohemagglutinin; $\mathrm{PMA}=$ phorbol myristate acetate .

also seen with other stimuli, such as PHA, tetanus toxoid, and anti-CD3 plus PMA, but at a level of significance that was not as great as that seen with the CD2 responses (Figure 1). Anti-CD3 or PMA used separately induced comparable levels of proliferation in the SLE and control groups.

All of the normal subjects had anti-CD2 antibody responses that were over $20,000 \mathrm{cpm}$, but 18 of the 57 SLE patients had responses that were lower than $20,000 \mathrm{cpm}$. This latter group was designated "low-responder," and the remaining SLE patients were designated "normal-responder." Almost all of the differences in the CD2 responses between the SLE patients and the control group were the result of the low-responder patients, many of whom showed counts that were only barely detectable over background in the presence of anti-CD2 antibodies. These low responses were noted at multiple durations of culture (day 2 to day 6 ), in the presence of higher concentrations of anti-CD2 antibodies (1:100), and when cells were precultured in medium alone for $24-48$ hours prior to stimulation (data not shown).

Data from the proliferation studies and from concurrent flow cytometric surface marker quantitation were then analyzed to determine whether other immunologic parameters correlated with the magnitude of the CD2 response, either in normal subjects or in SLE patients. As shown in Table 1, many of these parameters were significantly different between the SLE and control groups. The SLE group exhibited a marked T lymphopenia, which is consistent with findings from previous studies (1-3). The proportion of natural killer cells (CD56+) among the mononuclear 
Table 1. Correlation of immunologic parameters with CD2 activation responses in patients with systemic lupus erythematosus (SLE) and in normal control subjects*

\begin{tabular}{|c|c|c|c|c|c|}
\hline & \multirow[b]{2}{*}{$\begin{array}{l}\text { SLE patients } \\
(\mathrm{n}=57)\end{array}$} & \multirow[b]{2}{*}{$\begin{array}{l}\text { Control subjects } \\
(\mathrm{n}=32)\end{array}$} & \multirow[b]{2}{*}{$\begin{array}{c}P \\
\text { (SLE vs. control) }\end{array}$} & \multicolumn{2}{|c|}{$\begin{array}{l}\text { Correlation with } \\
\text { anti-CD2 } \\
\text { response }\end{array}$} \\
\hline & & & & $\begin{array}{c}P \\
(S L E)\end{array}$ & $\begin{array}{c}P \\
\text { (control) }\end{array}$ \\
\hline \multicolumn{6}{|l|}{ Proliferative response } \\
\hline Anti-CD2 & $38,967 \pm 4,099$ & $66,590 \pm 6,004$ & $<0.0001$ & - & - \\
\hline PHA & $48,077 \pm 3,340$ & $65,467 \pm 4,531$ & $<0.005$ & $<0.001$ & $<0.05$ \\
\hline Anti-CD3 & $7,932 \pm 1,320$ & $10,360 \pm 5,322$ & NS & NS & $<0.05$ \\
\hline PMA & $14,686 \pm 3,100$ & $17,801 \pm 4,547$ & NS & NS & $<0.05$ \\
\hline Anti-CD3 + PMA & $81,076 \pm 6,205$ & $114,827 \pm 7,797$ & 0.001 & $<0.01$ & NS \\
\hline Tetanus toxoid & $10,714 \pm 2,501$ & $23,116 \pm 2,435$ & $<0.005$ & NS & NS \\
\hline \multicolumn{6}{|l|}{ Surface marker } \\
\hline CD3 (T3) & $37 \pm 3$ & $63 \pm 3$ & $<0.0001$ & NS & NS \\
\hline CD4 (T4) & $21 \pm 2$ & $38 \pm 3$ & $<0.0001$ & NS & NS \\
\hline CD8 (T8) & $13 \pm 1$ & $16 \pm 2$ & NS & NS & NS \\
\hline CD2 (T11) & $31 \pm 3$ & $63 \pm 4$ & $<0.0001$ & NS & NS \\
\hline $\mathrm{CD} 4: \mathrm{CD} 8$ & $2.1 \pm 0.2$ & $2.9 \pm 0.3$ & $<0.05$ & NS & NS \\
\hline HLA-DR (Ia) & $11 \pm 1$ & $7 \pm 1$ & 0.01 & NS & NS \\
\hline CD11b (Mo1) & $9 \pm 1$ & $18 \pm 2$ & $<0.0001$ & NS & NS \\
\hline CD20 (B1) & $6 \pm 1$ & $3 \pm 0.4$ & $<0.005$ & NS & NS \\
\hline CD56 (HNKla) & $4 \pm 0.5$ & $10 \pm 1$ & $<0.0001$ & NS & NS \\
\hline CDw60 (UM4D4) & $11 \pm 1$ & $17 \pm 2$ & $<0.01$ & NS & NS \\
\hline CD25 (IL-2R) & $2 \pm 0.3$ & $2 \pm 0.4$ & NS & NS & $<0.001$ \\
\hline CD26 (Tal) & $6 \pm 1$ & $8 \pm 1$ & NS & NS & $<0.05$ \\
\hline CDw60/CD3 & $0.38 \pm 0.04$ & $0.24 \pm 0.02$ & $<0.05$ & NS & NS \\
\hline $\mathrm{CD} 25 / \mathrm{CD} 3$ & $0.07 \pm 0.01$ & $0.03 \pm 0.001$ & $<0.05$ & NS & $<0.001$ \\
\hline $\mathrm{CD} 26 / \mathrm{CD} 3$ & $0.19 \pm 0.03$ & $0.12 \pm 0.02$ & $<0.05$ & NS & $<0.05$ \\
\hline
\end{tabular}

* Values are the mean \pm SEM cpm (proliferative response) or the mean \pm SEM percentage of mononuclear cells positive over background fluorescence, as determined by flow cytometric analysis (surface markers). Terms in parentheses are other names that have been used to identify the cell surface markers listed. PHA = phytohemagglutinin; NS = not significant. PMA = phorbol myristate acetate; IL-2R = interleukin-2 receptor.

cell population was also reduced, but the proportion of B lymphocytes and the proportion of Ia + cells were increased. The calculated percentage of $T$ cells bearing markers of activation (CD25 and CD26) was marginally greater in the SLE group. Although the percentage of CDw60+ mononuclear cells was lower among the SLE patient group, the calculated proportion of $T$ cells that were CDw60+ was higher. (CDw60 is a marker of a $T$ cell subset that accumulates in autoimmune lesions $[44,50])$.

The reduced expression of CD2 was especially notable in the SLE group, and the proportion of CD2+ cells was somewhat lower than the proportion of CD3 + cells. This was, in part, due to the reduced intensity of CD2 expression that was seen in cells from many of the SLE subjects, causing some cells within the CD2 peak to fall just below the cutoff for background fluorescence (data not shown). The data, therefore, do not necessarily indicate the existence of a large CD3+, CD2- T cell subset in the SLE patients.
Furthermore, low-intensity expression of CD2 in SLE patients' cells did not appear to explain the low proliferative responses to anti-CD2 antibodies, since within the SLE group, no correlation was found between the proportion of cells bearing CD2 (or any other surface marker) and the CD2 activation response (Table 1). In the control group, but not the SLE group, the percentage of mononuclear cells and the calculated proportion of $\mathrm{T}$ cells bearing markers of $\mathrm{T}$ cell activation (CD25 and CD26) correlated positively with the CD2 response (Table 1). There was correlation of CD2 responses with other proliferative responses, although the relationships within the SLE group were different from those within the control group.

To determine whether the low CD2 pathway responses in SLE patients reflected the presence of excessive numbers of monocytes in culture or the inhibitory effects of monocytes and other non-T cells, proliferation was measured using isolated $\mathrm{T}$ cells that had been obtained by rosetting with sheep erythro- 
Table 2. Proliferative responses of mononuclear cell subsets from patients with systemic lupus erythematosus (SLE) and from a normal control subject to anti-CD2 and anti-CD3 antibodies*

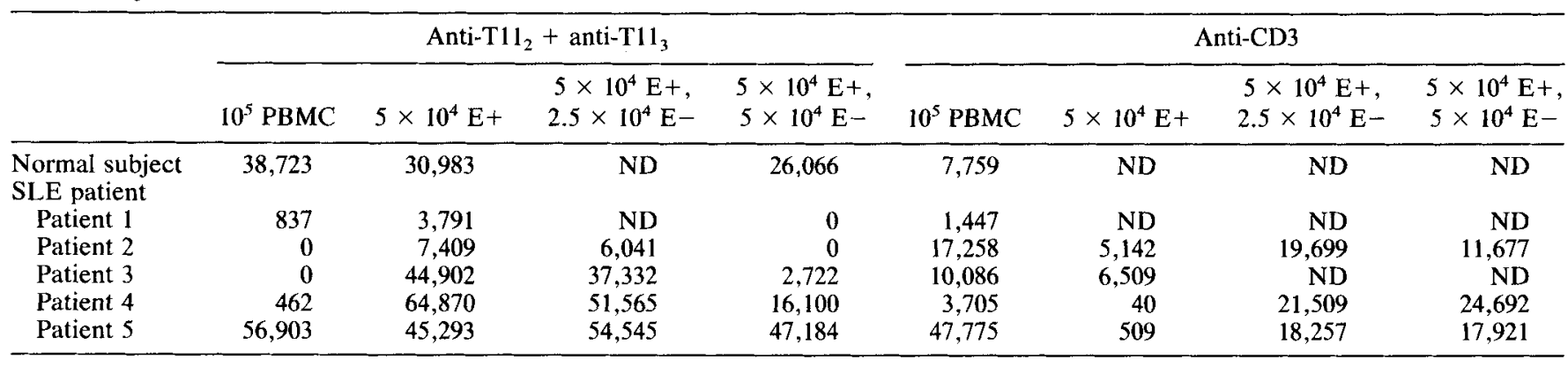

* Values are the mean $\mathrm{cpm}$ in triplicate cultures, as measured on day 4. Data are representative of the 12 subjects studied (2 normal controls and 10 SLE patients). E+ and E- cells were separated by rosetting with sheep erythrocytes. PBMC = peripheral blood mononuclear cells; ND $=$ not done

cytes. As shown in Table 2, removal of non-T cells from the mononuclear cell population restored to normal the low responses in some, but not all, SLE patients' cells. Therefore, the deficiencies in CD2 pathway function in low-responder SLE patients may be due to intrinsic $\mathrm{T}$ cell abnormalities, as well as the negative effects of non-T cells. Responses to anti-CD3 were lower in the absence of $\mathrm{E}$ - cells, since monocytes are important for the $\mathrm{T}$ cell response to soluble anti-CD3 (51).

Experiments were then performed to determine whether the anti-CD2 response in low-responder SLE subjects could be restored to normal by the addition of a second activation stimulus. In these experiments, 2 types of SLE low responders were studied, including some of the subjects described above, as well as a group of SLE patients whose CD2 responses became low after treatment with intravenous cyclophosphamide (38). The results did not differ between these groups of low responders, and the findings are therefore combined as a single group for discussion here.

The findings for 20 SLE low responders were compared with those of 12 SLE normal responders in terms of their response to anti-CD2 antibodies or PMA, or both. For cells from the SLE normal responders, the combination of anti-CD2 and PMA gave an additive, rather than a synergistic, response (Table 3). Despite also having a somewhat lower response to PMA, cells from the SLE low responders had a synergistic response to anti-CD2 antibodies plus PMA, yielding cpm that were not significantly different from the $\mathrm{cpm}$ in the normal-responder group. Of the $20 \mathrm{low}$ responders to anti-CD2, 17 had cpm $>20,000$ when PMA was included in the culture. Some reconstitution of the CD2 response was also seen when IL-2 (1-16 units/ml), instead of PMA, was added to the medium, although this was generally less effective (data not shown).

Taken together, the above data suggest that $\mathrm{T}$ cells from a subgroup of patients with SLE are not effectively activated by the triggering of $\mathrm{CD} 2$, although full activation can be restored by inclusion of a comitogenic stimulus. Defective responses could potentially reflect inadequate initial transmembrane signaling, which could, in turn, be due to insufficient induction of the $\mathrm{T} 11_{3}$ epitope. To determine whether the anti-T $11_{2}$ antibody induced prompt expression of the $\mathrm{T} 11_{3}$ epitope, SLE patient $\mathrm{T}$ cells were incubated with anti-T11 $11_{2}$, and then stained with anti- $111_{3}$ and fluorescein isothiocyanate-conjugated anti-mouse Ig that bound to the anti-T11 $1_{3}$, but not the anti-T11 $1_{2}$, antibody. Prompt expression of $\mathrm{T}_{1} 1_{3}(50-100 \%$ of $\mathrm{T}$

Table 3. Response of cells from patients with systemic lupus erythematosus (SLE) to anti-CD2 antibodies*

\begin{tabular}{lccc}
\hline & Anti-CD2 & PMA & Anti-CD2 + PMA \\
\hline Normal responders $(\mathrm{n}=12)$ & $54,719 \pm 5,805$ & $22,997 \pm 4,162$ & $80,360 \pm 10,454$ \\
Low responders $(\mathrm{n}=20)$ & $5,508 \pm 1,251$ & $9,555 \pm 1,828$ & $62,740 \pm 8,730$ \\
$P$ (normal vs. low) & $<0.0001$ & $<0.05$ & $>0.05$ \\
\hline
\end{tabular}

* See Patients and Methods for definitions of responder status. Values are the mean \pm SEM cpm. PMA = phorbol myristate acetate. 


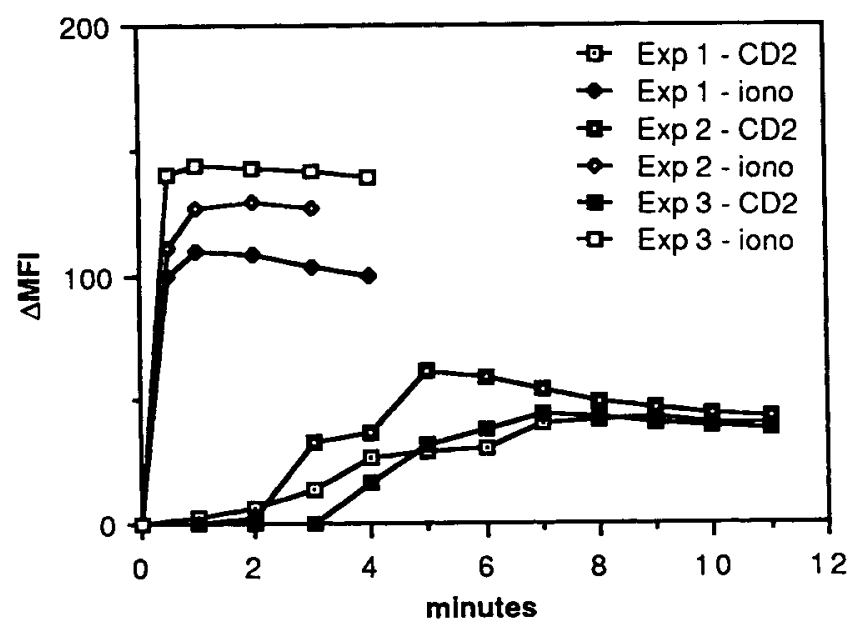

Figure 2. Generation of calcium fluxes in $\mathrm{T}$ cells from patients with systemic lupus erythematosus (SLE) by anti-CD2 antibodies. Cells were loaded with indo-1 and analyzed by flow cytometry. Anti-CD2 antibodies or ionomycin (iono) were added at time 0 . Values are the change in the mean fluorescence intensity ( $\triangle \mathrm{MFI})$ of the violet:blue ratio over time. Experiment $1=$ cells from a low responder to anti-CD2 antibodies; experiments 2 and $3=$ cells from 2 different normal responders (see Patients and Methods for details). Data are representative of 12 experiments (8 with SLE patients and 4 with control subjects).

cells positive within 30 minutes) occurred in all 6 experiments, regardless of the level of the proliferative response to anti-T11 $1_{2}$ plus anti-T11 $1_{3}$ (data not shown). The $\mathrm{T} 11_{2}$ and $\mathrm{T} 11_{3}$ epitopes were able to generate a transmembrane activation signal in all cases, as demonstrated by significant calcium fluxes in $T$ cells from both high- and low-responder SLE patients (Figure 2). Similar fluxes were observed with cells from control subjects (data not shown).

One of the components of $\mathrm{T}$ cell activation is induced expression of high-affinity IL-2 receptors that contain 2 distinct subunits (52). Experiments were therefore performed to measure both total and highaffinity IL-2R expression after anti-CD2 activation of $T$ cells from both low- and normal-responder SLE subjects and from normal controls. As shown in Table 4 , the SLE low responders tended to have lower expression of high-affinity and total IL-2R than did the other groups, but these differences did not, in general, achieve statistical significance. Considerable heterogeneity was present within each group. When total or high-affinity IL-2R expression was plotted against the response to anti-CD2 antibodies for all SLE patients whose data are included in Table 4 , a significant correlation was not detected (data not shown).
Table 4. Interleukin-2 receptor (IL-2R) expression following CD2 activation in cells from patients with systemic lupus erythematosus (SLE) and from normal control subjects*

\begin{tabular}{lcc}
\hline & $\begin{array}{c}\text { High-affinity } \\
\text { IL-2R }\end{array}$ & $\begin{array}{c}\text { Total } \\
\text { IL-2R }\end{array}$ \\
\hline $\begin{array}{l}\text { SLE low responders } \\
(\mathrm{n}=6)\end{array}$ & $498 \pm 103$ & $3,701 \pm 1,377$ \\
$\begin{array}{l}\text { SLE normal responders } \\
(\mathrm{n}=4)\end{array}$ & $818 \pm 421$ & $9,946 \pm 3,752$ \\
$\begin{array}{l}\text { Normal controls (n=3) } \\
P \text { (SLE low responders }\end{array}$ & $1,388 \pm 842$ & $10,026 \pm 1,573$ \\
$\quad \begin{array}{l}\text { vs. SLE normal } \\
\text { responders) }\end{array}$ & $\mathrm{NS}$ & $\mathrm{NS}$ \\
$P$ (SLE low responders & & \\
$\quad$ vs. normal controls) & $\mathrm{NS}$ & $<0.05$ \\
\end{tabular}

* See Patients and Methods for definitions of responder status. Values are expressed as the mean \pm SEM no. of IL-2R. NS $=$ not significant $(P>0.05)$.

To measure the production of IL-2, supernatants were collected from cultured SLE mononuclear cells that had been activated with a variety of stimuli. Representative findings are shown in Table 5. Only low levels of CTLL-2 proliferation occurred in the presence of supernatants from cultures activated with

Table 5. Interleukin-2 production following CD2 activation in cells from patients with systemic lupus erythematosus (SLE)*

\begin{tabular}{lrr}
\hline & PBMC & CTLL-2 \\
\hline Experiment 1 & & \\
Anti-CD2 & 4,262 & 38 \\
PMA & 185 & 0 \\
Anti-CD2 + PMA & 42,825 & 540 \\
Anti-CD3 + PMA & 37,747 & 701 \\
Experiment 2 & & \\
Anti-CD2 & 29,493 & 267 \\
PMA & 11,887 & 138 \\
Anti-CD2 + PMA & 38,173 & 3,565 \\
Anti-CD3 + PMA & 30,667 & 3,200 \\
Experiment 3 & & \\
Anti-CD2 & 5,047 & 162 \\
PMA & 1,004 & 0 \\
Anti-CD2 + PMA & 34,361 & 8,956 \\
Anti-CD3 + PMA & 34,125 & 4,354 \\
Experiment 4 & & \\
Anti-CD2 & 15,665 & 90 \\
PMA & 11,129 & 0 \\
Anti-CD2 + PMA & 153,954 & 2,024 \\
Anti-CD3 + PMA & 101,193 & 1,185 \\
\hline
\end{tabular}

* Values are the mean cpm in triplicate cultures and are representative of 16 experiments (10 low-responder SLE patients and 6 normal-responder SLE patients; see Patients and Methods for details and definitions of responder status). Experiments 1 and 2 used cells from SLE patients who had received intravenous cyclophosphamide within the preceding 3 months; experiments 3 and 4 used cells from SLE patients who had received no cytotoxic drugs during the preceding year. $\mathrm{PBMC}=$ peripheral blood mononuclear cells; $\mathrm{PMA}=$ phorbol myristate acetate. 
anti-CD2 antibodies, even when the anti-CD2 response was in the normal range (e.g., experiment 2 in Table 5). For the 6 experiments using supernatants from normal-responder SLE subjects, mean \pm SEM CTLL-2 proliferation was only $137 \pm 56 \mathrm{cpm}$, which was not different from that found for the lowresponder subjects. Similar low levels of CTLL-2 proliferation were seen using supernatants from PMAstimulated cultures. Supernatants of cells cultured with anti-CD2 plus PMA generally supported much higher levels of CTLL-2 proliferation than did supernatants of cells cultured with either stimulus alone. Comparing anti-CD2 plus PMA supernatants with antiCD2 supernatants, the degree of augmentation was $>10$-fold in 11 of 16 experiments (including all in Table 5 ), and $>3$-fold in 15 of 16 experiments. Again, no difference was found between low-responder and normal-responder SLE groups.

The data described above and in Table 5 were obtained using a 1:4 dilution of supernatant in the CTLL-2 cultures, but similar patterns were seen with dilutions ranging from $1: 2$ to $1: 16$. The data described are for supernatants collected from cultures that did not contain anti-IL-2R antibody: In all experiments, a blocking anti-IL-2R antibody was included in parallel initial cultures to prevent utilization of newly produced IL-2 (anti-TAC, at 1:100), and the results were virtually the same as those obtained in the absence of this antibody (data not shown). The results do not, therefore, demonstrate distinct patterns of IL-2 secretion in SLE low versus SLE normal responders following CD2 pathway activation.

Clinical parameters were then analyzed in the SLE patients to determine whether low CD2 responses correlated with the use of specific types of medications, the dosage of corticosteroids, or the clinical status. There was no significant positive or negative correlation between the magnitude of the response to anti-CD2 antibodies and the titer of antiDNA antibodies, the serum creatinine level, the age of the patients, or the dosage of prednisone. The range of dosages of prednisone taken by the low-responder group was $0-60 \mathrm{mg} / \mathrm{day}$, the same as that in the normal-responder group (except for 1 patient in the normal-responder group who was taking $120 \mathrm{mg} /$ day).

The CD2 responses of the SLE patients were then analyzed according to the presence or absence of the following clinical characteristics: high clinical activity score, renal disease, central nervous system disease, high erythrocyte sedimentation rate, serositis, cytopenia, hypocomplementemia $(\mathrm{CH} 50, \mathrm{C} 3$, or $\mathrm{C} 4)$,
Table 6. CD2 responses in clinical subsets of patients with sys" temic lupus erythematosus

\begin{tabular}{|c|c|c|c|}
\hline Clinical characteristic & $\begin{array}{c}\text { Feature present } \\
\text { at study, mean } \\
\text { cpm }\end{array}$ & $\begin{array}{c}\text { Feature absent } \\
\text { at study, mean } \\
\text { cpm }\end{array}$ & $P$ \\
\hline $\begin{array}{l}\text { Disease activity } 2 \text { or } 3 \\
\quad(0-3 \text { scale })\end{array}$ & $40,151(28)$ & $35,118(20)$ & 0.91 \\
\hline Renal disease & $39,502(30)$ & $37,549(17)$ & 0.96 \\
\hline CNS disease & $29,097(17)$ & $42,966(31)$ & 0.11 \\
\hline $\mathrm{ESR}>50 \mathrm{~mm} / \mathrm{hour}$ & $40,972(22)$ & $31,327(22)$ & 0.19 \\
\hline Scrositis & $24,521(15)$ & $45,487(32)$ & 0.03 \\
\hline Cytopenia & $37,942(10)$ & $38,906(36)$ & 0.96 \\
\hline Low complement & $35,294(23)$ & $39,168(20)$ & 0.75 \\
\hline \multicolumn{4}{|l|}{ Currently taking } \\
\hline NSAIDs & $44,211(14)$ & $35,969(31)$ & 0.41 \\
\hline Antimalarials & $53,104(7)$ & $36,707(38)$ & 0.18 \\
\hline Azathioprine & $40,470(7)$ & $38,211(39)$ & 0.83 \\
\hline
\end{tabular}

* The presence or absence of clinical variables at the time of study ( \pm 1 month) was determined retrospectively by chart review. Not all information was available for all patients, and the number represented is shown in parentheses. CNS = central nervous system; ESR = erythrocyte sedimentation rate; NSAIDs = nonsteroidal antiinflammatory drugs.

and current use of a nonsteroidal antiinflammatory drug, antimalarial agent, or azathioprine. Responses to anti-CD2 antibodies did not differ between the groups with or without these individual characteristics, except for serositis, which was associated with a modestly lower CD2 response (Table 6). The data indicate that low CD2 responses in a subset of SLE patients are not accounted for by overall disease activity or by use of specific medications.

\section{DISCUSSION}

In this study, the integrity of CD2-mediated $\mathrm{T}$ cell activation was investigated in the peripheral blood cells of 57 SLE patients and 32 healthy control subjects. Significantly lower proliferative responses to a mitogenic pair of anti-CD2 antibodies were noted in the SLE patients. The difference between the SLE and control groups could be accounted for by a lowresponder subset of SLE patients, which composed $\sim 30 \%$ of the SLE group. Other T cell responses were also reduced in the SLE group, but the difference was especially prominent for the CD2 response.

Most forms of $\mathrm{T}$ cell activation, including stimulation with mitogenic lectins or soluble antigen, require substantial accessory cell help, which is usually provided by monocytes. Intact $\mathrm{T}$ cell responses therefore depend upon normal function of both monocytes and $\mathrm{T}$ cells. Responses to soluble anti-CD3 also require monocytes, in part to bind the Fc portion of the 
anti-CD3 antibodies to $\mathrm{Fc}$ receptors on the monocyte surface (52), a requirement that can be bypassed by the addition of PMA (53). The anti-CD2 antibodies used in these studies activate normal $\mathrm{T}$ cells with little or no need for monocytes (33) and are therefore of special value as a direct probe of $T$ cell function. This may be particularly useful in SLE, a disease in which monocyte function may be abnormal (54).

Multiple abnormalities of surface antigen expression were noted on SLE mononuclear cells, including $\mathrm{T}$ lymphopenia and reduced $\mathrm{CD} 2$ expression. None of these parameters correlated, however, with the level of CD2 responses, which indicates that defective responses did not exclusively reflect low CD2 expression. In the control group, the level of the $\mathrm{CD} 2$ response correlated with the proportion of $\mathrm{T}$ cells bearing markers of activation. In contrast, in the SLE group, despite higher proportions of activated cells, no such correlation was seen. This suggests that CD2 responses may be regulated differently in SLE patients, even in those who are normal responders, than in healthy control subjects. Validation of this hypothesis will, however, require better understanding of the $\mathrm{CD} 2$ activation pathway.

Defective $\mathrm{CD} 2$ responses in low-responder SLE patients could be normalized by costimulation with minimally mitogenic doses of the phorbol ester PMA. In this respect, SLE low-responder $T$ cells resembled normal thymocytes, which require 2 signals to proliferate through the $\mathrm{CD} 2$ pathway $(34,55)$. In the case of thymocytes, anti-CD2 antibodies induced IL-2R expression, but not IL-2 production-proliferation occurred only if IL-2 was exogenously provided (34) or if its synthesis was induced by PMA (55). In the case of SLE low responders, experiments designed to precisely localize the $C D 2$ activation defect to either inadequate transmembrane signaling, IL-2R expression, or IL-2 production did not yield a clear-cut answer. Expression of the $\mathrm{T} 11_{3}$ epitope and induction of calcium fluxes were normal in SLE low responders. Cells from SLE low responders tended to show lower high-affinity and total IL-2R induction by anti-CD2, but the differences between this group and the SLE normal responders or the healthy controls generally did not reach statistical significance.

Interpretation of IL-2R expression in these experiments is complicated by the dependence of the full expression of IL-2R on the secretion of IL-2 (56). Detectable production of IL-2 following CD2 stimulation was low in both SLE low responders and SLE normal responders, unless PMA was added. It is possible that SLE normal responders produce low, but functionally important, amounts of IL-2 that are not detectable by currently available assays, and that inadequate IL-2 production limits proliferation in some of the SLE low responders. Alternatively, SLE normal responders might produce non-IL-2 $T$ cell autocrine growth factors following CD2 activation, to a greater extent than the SLE low responders. The low IL-2 production found in this study closely parallels findings with PHA stimulation of $\mathrm{T}$ cells from patients with either active or inactive SLE (57).

Patients with active SLE are deficient in the CD4 +, CD45R + suppressor inducer T cell subset (20), which has been reported to respond particularly well to CD2 stimulation (58). Although this subset was not measured in the present study, it is unlikely that deficiency of these cells would account for the SLE low-responder group, since (a) CD2 responses did not correlate with disease activity, and (b) $\mathrm{T}$ cell subsets other than the $\mathrm{CD} 4+, \mathrm{CD} 45 \mathrm{R}+$ population normally also respond vigorously to CD2 activation, as indicated by efficient triggering of helper function for immunoglobulin production by anti-CD2 antibodies (59).

One potential explanation for low CD2 responses might be the presence of a (non-T) cell subset within the mononuclear cell population that suppresses the $\mathrm{CD} 2$ response in the low-responder individuals. In some but not all low responders, purification of $T$ cells prior to culture significantly enhanced the CD2 response (Table 2). Taken together, the data suggest that the defective responses to anti-CD2 antibodies in the SLE low-responder individuals may represent an intrinsic $\mathrm{T}$ cell defect (or heterogeneous group of defects), the regulatory effects of non-T cells, and possibly, abnormal $\mathrm{T}$ cell responses to such regulatory signals. Low responses do not appear to be the result of SLE-induced organ failure or administration of corticosteroids. Because initial signaling events (as judged by calcium fluxes in the presence of anti-CD2 antibodies) appear to be intact, any intrinsic $T$ cell defects may lie at later stages of the $T$ cell activation process. Whether such defects relate in any way to the pathogenesis of SLE will require further investigation. It is certainly possible that similar abnormalities could be present in other autoimmune diseases, and that such abnormalities could be a secondary consequence of autoimmune processes.

A role for the $\mathrm{CD} 2$ pathway has been postulated in the selection of $\mathrm{T}$ cells in the human thymus, since in vitro triggering of the thymocyte antigen receptor complex could be shown to provide a negative signal 
under conditions in which $\mathrm{CD} 2$ triggering provided a positive signal $(55,60)$. Based on these findings, it was hypothesized that thymocytes not subject to negative selection (cells lacking high-affinity autoreactivity) could expand and differentiate by activation through CD2 (60), particularly since a functional ligand of CD2 has been shown to be present in the thymus $(36,37)$. If responses to $\mathrm{CD} 2$ in low-responder individuals were defective throughout $\mathrm{T}$ cell ontogeny, including the thymocyte stage, a potential consequence could be alterations of the thymic selection process that might predispose to the later development of autoimmune disease. No data that directly support this hypothesis are currently available, however.

It is intriguing that in SLE normal-responder subjects, intravenous cyclophosphamide treatment frequently leads to conversion to a CD2 low-responder state, despite preservation of other $\mathrm{T}$ cell proliferative responses (38). This indicates that even in SLE normal responders, the CD2 pathway is uniquely vulnerable and can be regulated in ways distinct from those of other $\mathrm{T}$ cell responses. (No information, however, is available regarding the effects of cyclophosphamide on CD2 responses in individuals without autoimmune disease.) Both constitutive and cyclophosphamideinduced $\mathrm{CD} 2$ low responsiveness were normalized by small concentrations of the comitogen PMA. This raises the possibility that signal transduction events normally culminating in the activation of protein kinase $\mathrm{C}$ were defective in these low responders, and that PMA bypassed the defective signaling step(s). Alternatively, the augmenting effect of PMA could reflect modulation of the expression of various $T$ cell surface structures and/or effects on the expression of genes essential to $\mathrm{T}$ cell activation by mechanisms other than activation of protein kinase $\mathrm{C}$. Additional work will be necessary to resolve these issues and to precisely identify the mechanisms of abnormal activation through CD2 in patients with SLE.

\section{ACKNOWLEDGMENTS}

We thank Patricia Bohlke and Sheila Chang for technical assistance, Clare Rogers for performing flow cytometry, and Nancy Forster and Susan Brushingham for preparation of the manuscript. We are grateful to Drs. Stuart Schlossman and Ellis Reinherz for the generous gifts of monoclonal antibodies.

\section{REFERENCES}

1. Rivero SJ, Llorente L, Díaz-Jouanen E, AlarcónSegovia D: T-lymphocyte subpopulation in untreated
SLE: variations with disease activity. Arthritis Rheum 20:1169-1173, 1977

2. Lipnick RN, Balow JE, Tsokos GC: Lymphocyte subpopulations in patients with systemic lupus erythematosus. Clin Immunol Immunopathol 31:181-199, 1984

3. Moutsopoulos H, Fye KH, Sawada S, Becker MJ, Goldstein A, Talal N: In vitro effect of thymosin on T-lymphocyte rosette formation in rheumatic diseases. Clin Exp Immunol 26:563-573, 1976

4. Morimoto C, Reinherz EL, Schlossman SF, Schur PH, Mills JA, Steinberg AD: Alterations in immunoregulatory $\mathrm{T}$ cell subsets in active systemic lupus erythematosus. J Clin Invest 66:1171-1174, 1980

5. Bakke AC, Kirkland PA, Kitridou RC, Quismorio FP Jr, Rea T, Ehresmann GR, Horwitz DA: T lymphocyte subsets in systemic lupus erythematosus: correlations with corticosteroid therapy and disease activity. Arthritis Rheum 26:745-750, 1983

6. Smolen JS, Chused TM, Leiserson WM, Reeves JP, Alling D, Steinberg AD: Heterogeneity of immunoregulatory T-cell subsets in systemic lupus erythematosus: correlations with clinical features. Am J Med 72:783790,1982

7. Gottlieb AB, Lahita RG, Chiorazzi N, Kunkel HG: Immune function in systemic lupus erythematosus: im: pairment of in vitro $\mathrm{T}$-cell proliferation and in vivo antibody response to exogenous antigen. $J$ Clin Invest 63:885-892, 1979

8. Balow JE, Tsokos GC: T and B lymphocyte function in patients with lupus nephritis: correlation with renal pathology. Clin Nephrol 21:93-97, 1984

9. Phillips R, Lomnitzer R, Rabson AR: Modulation of the sodium periodate $\left(\mathrm{NaIO}_{4}\right)$ response in systemic lupus erythematosus (SLE): effect of interleukin-1 (IL-1), interleukin-2 (IL-2), phorbol myristate acetate (PMA), and indomethacin. Clin Immunol Immunopathol 34:77-83, 1985

10. Tovar Z, Dauphinee MJ, Talal N: Defective induction of T-cell help and natural killing following anti-CD3 stimulation of autoimmune lymphocytes. J Autoimmunity 1:327-337, 1988

11. Alcocer-Varela J, Alarćon-Segovia D: Decreased production of and response to interleukin- 2 by cultured lymphocytes from patients with systemic lupus erythematosus. J Clin Invest 69:1388-1395, 1982

12. Linker-Israeli M, Bakke AC, Quismorio FP Jr, Horwitz DA: Correction of interleukin-2 production in patients with systemic lupus erythematosus by removal of spontaneously activated suppressor cells. J Clin Invest 75: 762-768, 1985

13. Miyasaka N, Nakamura T, Russell IJ, Talal N: Interleukin 2 deficiencies in rheumatoid arthritis and systemic lupus erythematosus. Clin Immunol Immunopathol 31: 109-117, 1984

14. Huang Y-P, Miescher PA, Zubler RH: The interleukin 2 
secretion defect in vitro in systemic lupus erythematosus is reversible in rested cultured $\mathrm{T}$ cells. J Immunol 137:3515-3520, 1986

15. Ishida $H$, Kumagai $S$, Umehara $H$, Sano $H$, Tagaya $Y$, Yodoi J, Imura H: Impaired expression of high affinity interleukin-2 receptor on activated lymphocytes from patients with systemic lupus erythematosus. J Immunol 139:1070-1074, 1987

16. Murakawa Y, Sakane T: Deficient phytohemagglutinininduced interleukin-2 activity in patients with inactive systemic lupus erythematosus is correctable by the addition of phorbol myristate acetate. Arthritis Rheum 31:826-833, 1988

17. Tanaka T, Saiki O, Negoro S, Igarashi T, Kuritani T, Hara H, Suemura M, Kishimoto S: Decreased expression of interleukin-2 binding molecules (p70/75) in T cells from patients with systemic lupus erythematosus. Arthritis Rheum 32:552-559, 1989

18. Morimoto $\mathrm{C}$, Abe $\mathrm{T}$, Homma $\mathrm{M}$ : Altered function of suppressor $\mathrm{T}$ lymphocytes in patients with active systemic lupus erythematosus: in vitro immune response to autoantigen. Clin Immunol Immunopathol 13:161-170, 1979

19. Matsumoto K, Osakabe K, Katayama H, Okano K, Yoshizawa N, Ohi H, Hatano M: Defective concanavalin A-induced suppressor cell activity in lupus nephritis. Int Arch Allergy Appl Immunol 75:48-51, 1984

20. Morimoto C, Steinberg AD, Letvin NL, Hagan M, Takeuchi T, Daley J, Levine H, Schlossman SF: A defect of immunoregulatory $\mathrm{T}$ cell subsets in systemic lupus erythematosus patients demonstrated with anti2H4 antibody. J Clin Invest 79:762-768, 1987

21. Takeuchi T, Tanaka S, Steinberg AD, Matsuyama $T$, Daley J, Schlossman SF, Morimoto C: Defective expression of the $2 \mathrm{H} 4$ molecule after autologous mixed lymphocyte reaction activation in systemic lupus erythematosus patients. J Clin Invest 82:1288-1294, 1988

22. McInerney MF, Clough JD, Senitzer D, Cathcart MK: Two distinct subsets of patients with systemic lupus erythematosus. Clin Immunol Immunopathol 49:116132,1988

23. Sakane T, Steinberg AD, Green T: Failure of autologous mixed lymphocyte reactions between $T$ and non- $T$ cells in patients with systemic lupus erythematosus. Proc Natl Acad Sci USA 75:3464-3468, 1978

24. Winfield JB, Winchester RJ, Wernet P, Fu SM, Kunkel HG: Nature of cold-reactive antibodies to lymphocyte surface determinants in systemic lupus erythematosus. Arthritis Rheum 18:1-8, 1975

25. Winfield JB, Winchester RJ, Kunkel HG: Association of cold-reactive antilymphocyte antibodies with lymphopenia in systemic lupus erythematosus. Arthritis Rheum 18:587-594, 1975

26. Morimoto C, Reinherz EL, Abe T, Homma M, Schlossman SF: Characteristics of anti-T cell antibodies in SLE: evidence for selective reactivity with normal suppressor cells defined by monoclonal antibodies. Clin Immunol Immunopathol 16:474 484,1980

27. Morimoto C, Reinherz EL, Distaso JA, Steinberg AD, Schlossman SF: Relationship between systemic lupus erythematosus $\mathrm{T}$ cell subsets, anti-T cell antibodies and T cell functions. J Clin Invest 73:689-700, 1984

28. Yamada A, Cohen PL, Winfield JB: Subset specificity of antilymphocyte antibodies in systemic lupus erythematosus: preferential reactivity with cells bearing the $\mathrm{T} 4$ and autologous erythrocyte receptor phenotypes. Arthritis Rheum 28:262-270, 1985

29. Winfield JB, Shaw M, Yamada A, Minota S: Subset specificity of antilymphocyte antibodies in systemic lupus erythematosus. 1I. Preferential reactivity with $\mathrm{T} 4+$ cells is associated with relative depletion of autologous T4+ cells. Arthritis Rheum 30:162-168, 1987

30. Minota S, Winfield JB: Identification of three major target molecules of $\mathrm{IgM}$ antilymphocyte autoantibodies in systemic lupus erythematosus. J Immunol 139:3644 3651,1987

31. Tanaka S, Matsuyama T, Steinberg AD, Schlossman SF, Morimoto C: Antilymphocyte antibodies against CD4 $+2 \mathrm{H} 4+$ cell populations in patients with systemic lupus erythematosus. Arthritis Rheum 32:398-405, 1989

32. Howard FD, Ledbetter JA, Wong J, Bieber CP, Steinson EB, Herzenberg LA: A human T lymphocyte differentiation marker defined by monoclonal antibodies that block $\mathrm{E}$ rosette formation. J Immunol 126:2117-2122, 1981

33. Meuer SC, Hussey RE, Fabbi M, Fox DA, Acuto O, Fitzgerald KA, Hodgdon JC, Protentis JP, Schlossman SF, Reinherz EL: An alternative pathway of $\mathrm{T}$ cell activation: a functional role for the $50 \mathrm{KD}$ T11 sheep erythrocyte receptor protein. Cell 36:897-906, 1984

34. Fox DA, Hussey RE, Fitzgerald KA, Bensussan A, Daley JF, Schlossman SF, Reinherz EL: Activation of human thymocytes via the $50 \mathrm{KD}$ T11 sheep erythrocyte binding protein induces the expression of interleukin 2 receptors on both $\mathrm{T} 3+$ and $\mathrm{T} 3-$ populations. J Immunol 134:330-335, 1985

35. Selveraj P, Plunkett ML, Dustin M, Sanders ME, Shaw $\mathrm{S}$, Springer TA: The T lymphocyte glycoprotein CD2 binds the cell surface ligand LFA-3. Nature 326:400 403,1987

36. Denning SM, Dustin ML, Springer TA, Singer KH, Haynes BF: Purified lymphocyte function-associated antigen-3 (LFA-3) activates human thymocytes via the CD2 pathway. J Immunol 141:2980-2985, 1988

37. Vollger LW, Tuck DT, Springer TA, Haynes BF, Singer $\mathrm{KH}$ : Thymocyte binding to human thymic epithelial cells is inhibited by monoclonal antibody to CD-2 and LFA-3 antigens. J Immunol 138:358-363, 1987

38. McCune WJ, Golbus J, Zeldes W, Bohlke P, Dunne R, Fox DA: Clinical and immunologic effects of monthly 
administration of intravenous cyclophosphamide in severe systemic lupus erythematosus. N Engl J Med 318:1423-1431, 1988

39. Tan EM, Cohen AS, Fries JF, Masi AT, McShane DJ, Rothfield NF, Schaller JG, Talal N, Winchester RJ: The 1982 revised criteria for the classification of systemic lupus erythematosus. Arthritis Rheum 25:1271-1277, 1982

40. Meuer SC, Hodgdon JC, Hussey RE, Protentis JP, Schlossman SF, Reinherz EL: Antigen-like effects of monoclonal antibodies directed at receptors on human $T$ cell clones. J Exp Med 158:988-993, 1983

41. Reinherz EL, Meuer SC, Fitzgerald KA, Hussey RE, Levine H, Schlossman SF: Antigen recognition by human T lymphocytes is linked to surface expression of the T3 molecular complex. Cell 30:735-743, 1982

42. Meuer SC, Schlossman SF, Reinherz EL: Clonal analysis of human cytotoxic lymphocytes: $\mathrm{T} 4+$ and $\mathrm{T} 8+$ effector $\mathrm{T}$ cells recognize products of different major histocompatibility complex regions. Proc Natl Acad Sci USA 70:4395-4399, 1982

43. Fox DA, Hussey RE, Fitzgerald KA, Acuto O, Poole C, Palley L, Daley JF, Schlossman SF, Reinherz EL: Ta1, a novel $105 \mathrm{KD}$ human $\mathrm{T}$ cell activation defined by a monoclonal antibody. J Immunol 133:1250-1256, 1984

44. Higgs JB, Zeldes W, Kozarsky K, Schteingart M, Kan L, Bohlke P, Krieger K, Davis W, Fox DA: A novel pathway of human $T$ lymphocyte activation: identification by a monoclonal antibody generated against a rheumatoid synovial T cell line. J Immunol 140:37583765,1988

45. Stashenko P, Nadler LM, Hardy R, Schlossman SF: Characterization of a human B lymphocyte-specific antigen. J Immunol 125:1678-1685, 1980

46. Nadler LM, Stashenko P, Hardy R, Pesando JM, Yunis EJ, Schlossman SF: Monoclonal antibodies defining serologically distinct HLA-D/DR related Ia-like antigens in man. Hum Immunol 1:77-90, 1981

47. Hercend T, Griffin JD, Bensussan A, Schmidt RE, Edson MA, Brennan A, Murray C, Daley JF, Schlossman SF, Ritz J: Generation of monoclonal antibodies to a human natural killer clone: characterization of two natural killer-associated antigens, $\mathrm{NKH} 1$ and $\mathrm{NKH} 2$, expressed on subsets of large granular lymphocytes. J Clin Invest 75:932-943, 1985

48. Todd RF III, Nadler LM, Schlossman SF: Antigens on human monocytes identified by monoclonal antibodies. J Immunol 126:1435-1442, 1981

49. Rabinovitch PS, June CH, Grossmann A, Ledbetter JA: Heterogeneity among $T$ cells in intracellular free calcium responses after mitogen stimulation with PHA or antiCD3: simultaneous use of indo- 1 and immunofluores- cence with flow cytometry. J Immunol 137:952-961, 1986

50. Baadsgaard O, Tong P, Elder JT, Hansen ER, Ho V, Hammerberg C, Lange-Vejlsgaard G, Fox DA, Fisher G, Chan LS, Voorhees JJ, Cooper KD: UM4D4+ (CDw60) $\mathrm{T}$ cells are compartmentalized into psoriatic skin and release lymphokines that induce a keratinocyte phenotype expressed in psoriatic lesions. J Invest Dermatol 95:275-282, 1990

51. Clement LT, Tilden AB, Dunlap NE: Analysis of the monocyte $\mathrm{Fc}$ receptors and antibody-mediated cellular interactions required for the induction of $\mathrm{T}$ cell proliferation by anti-T3 antibodies. J Immunol 135:165-171, 1985

52. Sharon M, Klausner RD, Cullen BR, Chizzonite R, Leonard WJ: Novel interleukin-2 receptor subunit detected by cross-linking under high-affinity conditions. Science 234:859-863, 1986

53. Hara T, Fu SM: Human T cell activation. I. Monocyteindependent activation and proliferation induced by anti-T3 monoclonal antibody in the presence of tumor promoter 12-0-tetradecanoyl phorbol-13 acetate. J Exp Med 161:641-656, 1985

54. Phillips R, Lomnitzer R, Wadee AA, Rabson AR: Defective monocyte function in patients with systemic lupus erythematosus. Clin Immunol Immunopathol 34: 69-76, 1985

55. Ramarli D, Fox DA, Reinherz EL: Selective inhibition of interleukin-2 gene function following thymocyte antigen/major histocompatibility complex receptor crosslinking: possible thymic selection mechanism. Proc Natl Acad Sci USA 84:8598-8602, 1987

56. Depper JM, Leonard WJ, Drogula C, Kronke M, Waldmann TA, Greene WC: Interleukin-2 (IL-2) augments transcription of the IL-2 receptor gene. Proc Natl Acad Sci USA 82:4230-4234, 1985

57. Wigfall DR, Sakai RS, Wallace DJ, Jordan SC: Interleukin-2 receptor expression in peripheral blood lymphocytes from systemic lupus erythematosus patients: relationship to clinical activity. Clin Immunol Immunopathol 47:354-362, 1988

58. Matsuyama T, Anderson P, Daley JF, Schlossman SF, Morimoto $\mathrm{C}$ : $\mathrm{CD} 4+2 \mathrm{H} 4+$ cells are preferentially activated through the CD2 pathway. Eur J Immunol 18: 1473-1476, 1988

59. Juy D, Sterkers G, Bernard A, Levy JP: Frequency analysis of human peripheral blood B cells sensitive to CD2 monoclonal antibody-activated T cells. Hum Immunol 19:225-233, 1987

60. Fox DA, Schlossman SF, Reinherz EL: Regulation of the alternative pathway of $\mathrm{T}$ cell activation by anti-T3 monoclonal antibody. J Immunol 136:1945-1950, 1986 